\title{
Profile of the leather processing/ and production units of Kanpur
}

\section{Iti Dubey and Meenu Srivastava}

Received: 14.05.2019; Revised: 08.10.2019; Accepted: 22.10.2019

See end of the paper for authors' affiliations

Meenu Srivastava

Department of Textiles and Apparel Designing, College of Community and Applied Sciences, Maharana Pratap University of Agriculture and Technology, Udaipur (Rajasthan) India Email : meenuclt@yahoo.com
ABSTRACT : The Indian Leather Industry comprises of major segments namely Footwear, Finished Leather, Leather Goods, Leather Garments, Footwear Components and Saddlery and Harness. All these segments have high growth potential. The leather units of Kanpur are renowned for high quality leather products and realistic pricing. The researcher selected 9 leather processing/ and production units of Kanpur city from different areas of Kanpur city for conducting survey work. The study was conducted with the objective to investigate the profile of leather processing and/ production industries of Kanpur city.

KEY WORDS: Profile, Leather, Processing, Production, Industries, Kanpur

- HOW TO CITE THIS PAPER : Dubey, Iti and Srivastava, Meenu (2019). Profile of the leather processing/ and production units of Kanpur. Asian J. Home Sci., 14 (2) : 297-303, DOI: 10.15740/HAS/ AJHS/14.2/297-303. Copyright@ 2019: Hind Agri-Horticultural Society. 